\title{
EXPERIMENTAL STUDY ON LOAD CARRYING CAPACITY OF STEEL CONCRETE COMPOSITE COLUMN UNDER AXIAL COMPRESSION
}

\author{
S.Prabhakaran ${ }^{1}$ and S.Kalaiselvi ${ }^{2}$
}

\begin{abstract}
This paper presents design of steel - concrete in-filled composite columns with and without shear connectors. A Column length of $1.04 \mathrm{~m}$ has been proposed with steel thickness of $1.5 \mathrm{~mm}$. The column has been fabricated with the infilling of $\mathrm{M}_{20}$ grade of concrete. The red oxide paint has been applied on the column to prevent from rusting. The axial compression load carrying capacity of steel-concrete in filled composite columns with and without connectors has been found out by using the loading frame machine of capacity of 200 tonnes the ultimate strength of the in-filled composite column with and without shear connectors has been noted. The failure modes of both the in-filled columns have been observed. It is evident that the load carrying capacity of column with shear connectors is high compared to column without shear connectors.

Keywords: in-filled composite column, shear connectors.
\end{abstract}

\section{INTRODUCTION}

A steel-concrete composite column is a compression member, comprising either a concrete encased hot-rolled steel section or a concrete filled tubular section of hot-rolled steel and is generally used as a load-bearing member in a composite framed structure. The most effective utilization of steel and concrete is achieved (both concrete and steel properties are used for full advantage). Keeping the span and loading unaltered, a more economical steel Section (in terms of depth and weight) is achievable in composite construction compared with conventional non-composite construction. Because of its larger stiffness, composite columns have less deflection than Steel columns.

\section{Methodology}

The first step in methodology involves about the study of the literature, and the next step is selection of material for fabrication of in-fill composite columns with and without shear connectors. Further fabrication of steel for both the columns is done with and without shear connectors. The mix proportion for M20 grade of concrete which is to be filled in column is carried out. Followed by casting of columns has been done. After certain duration of curing the ultimate load carrying capacity of column with and without connectors is tested using loading frame machine. The numerical analysis of both the composite columns using ANSYS has been carried out. Finally the numerical and experimental test result of both the in-filled composite columns with and without connectors is compared.

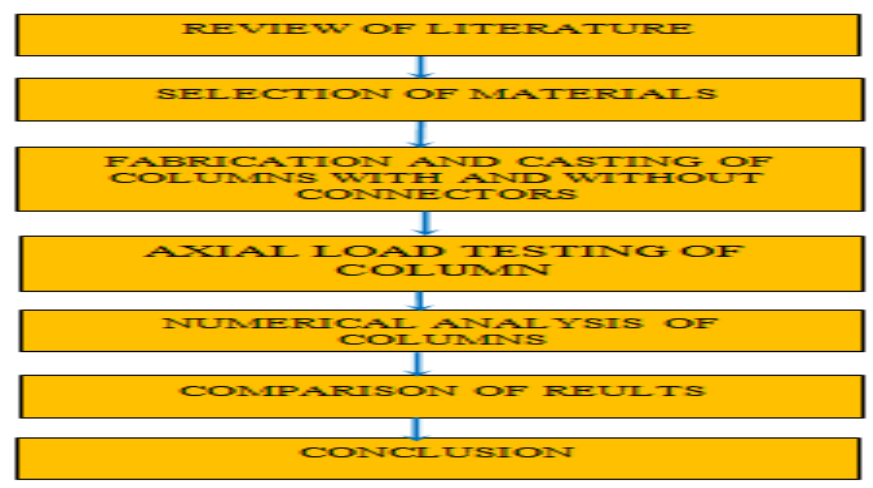

Fig1: Methodology

\footnotetext{
${ }^{1}$ Department of Civil Engineering, Sona College of Technology, Salem

${ }^{2}$ Department of Civil Engineering, Sona College of Technology, Salem
} 


\section{MATERIALS USED}

Generally steel and concrete is used as a major material. Steel sheet of $1.5 \mathrm{~mm}$ thickness are used for fabrication of two rectangular steel sections with and without connectors. The fabricated rectangular steel sections are given below in fig 2 and fig 3. The connectors ( 3 inch bolts) are used for welding in one column for good bond between steel and concrete. Concrete is used as a filling material. The M20 grade of concrete is used for filling in both the columns. The red oxide paint is used for applying on the surface of steel columns to prevent the column from rusting.

\section{DIMENSIONS}

The dimensions of both the in-filled composite column with and without shear connectors are tabulated below. The fabricated in-filled columns sections are shown in Fig 2 and Fig3. Seven connectors are welded in column 2 with a spacing of $130 \mathrm{~mm}$ as shown in Fig 2 .

\section{TABLE 1: DIMENSIONS OF COMPOSITE COLUMN}

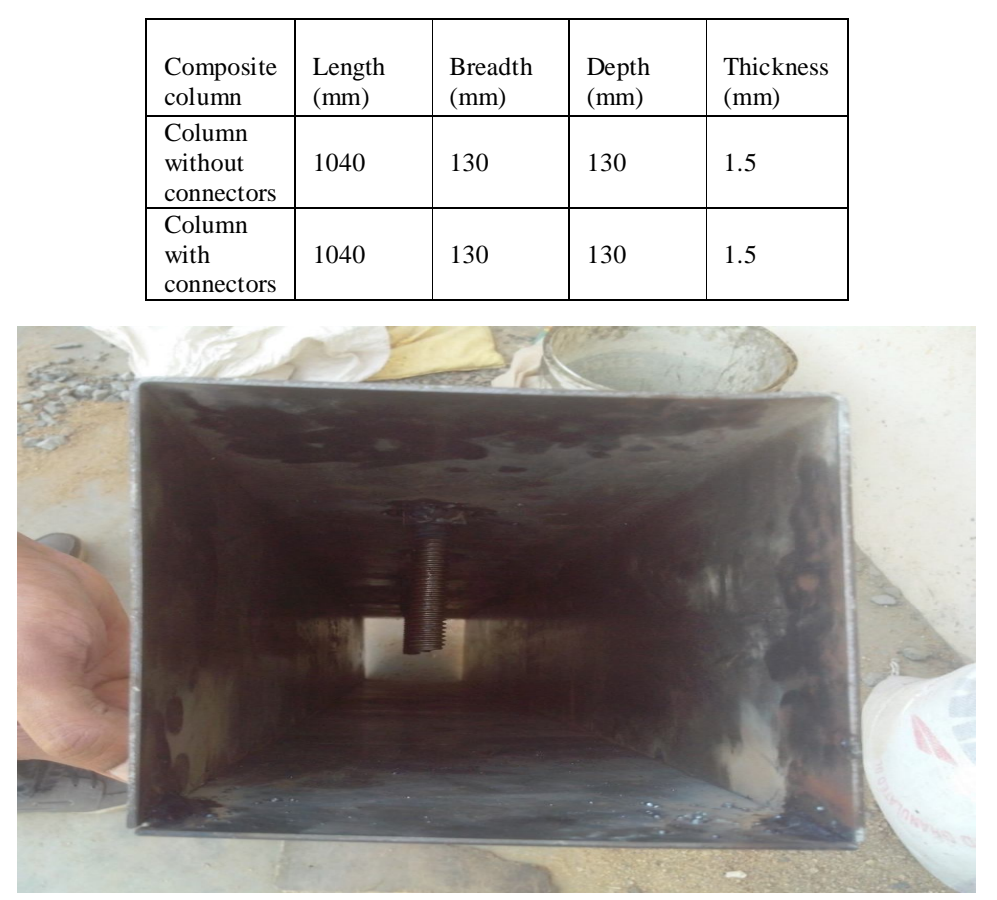

Fig2: Column with connectors (Column 2)

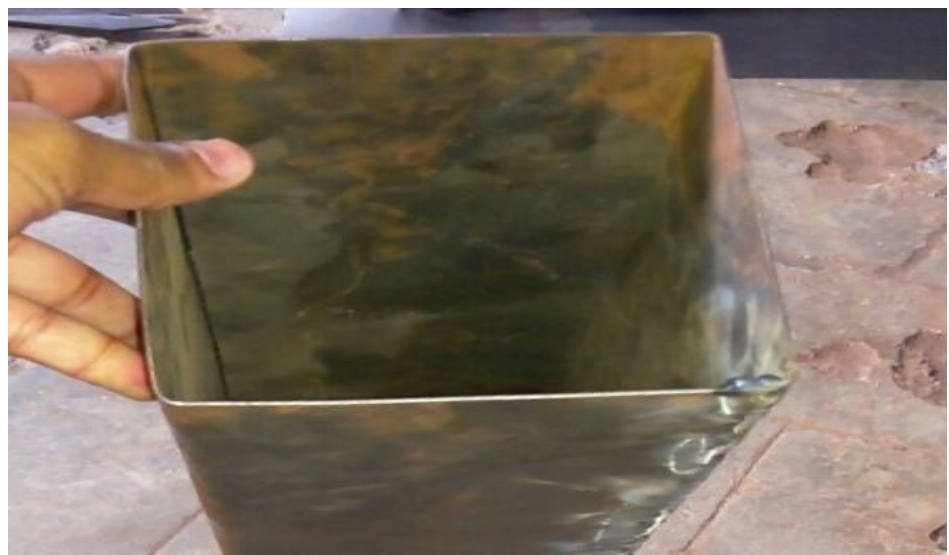

Fig3: Column without connectors (column 1) 


\section{CASTING OF COLUMNS}

The M20 grade of concrete is mixed properly and poured in fabricated in-filled steel sections. The compaction is done properly by using steel rod. Further red oxide is applied on the outer surface of the column to prevent column from rusting.

TABLE 2: MIX PROPORTION

\begin{tabular}{|l|l|l|l|}
\hline $\begin{array}{l}\text { Cement } \\
\left(\mathbf{k g} / \mathbf{m}^{\mathbf{3}}\right)\end{array}$ & $\begin{array}{l}\text { Fine } \\
\text { Aggregate } \\
\left(\mathbf{k g} / \mathbf{m}^{3}\right)\end{array}$ & $\begin{array}{l}\text { Coarse } \\
\text { Aggregate } \\
\left(\mathbf{k g} / \mathbf{m}^{3}\right)\end{array}$ & $\begin{array}{l}\text { Water Cement } \\
\text { ratio }\end{array}$ \\
\hline 383 & 727 & 1103 & 0.5 \\
\hline 1 & 1.81 & 2.87 & 0.5 \\
\hline
\end{tabular}

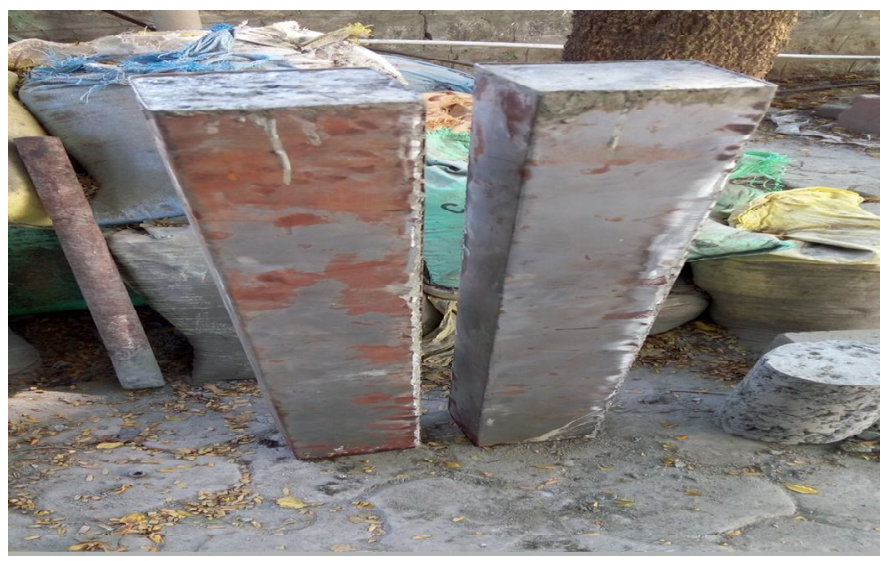

Fig5: Casted Columns

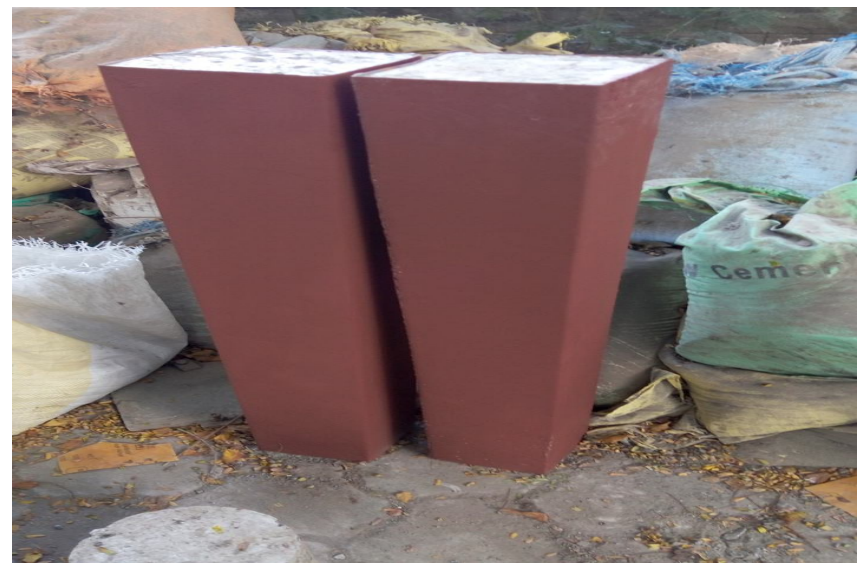

Fig 6: Columns painted with red oxide

\section{TESTING OF COLUMNS}

The columns are tested by using loading frame machine of capacity of 200 tonnes. Simply supported conditions are used for testing of both the columns with and without connectors. The axial load is applied to columns from bottom using hydraulic jack as shown in Fig7. Below 


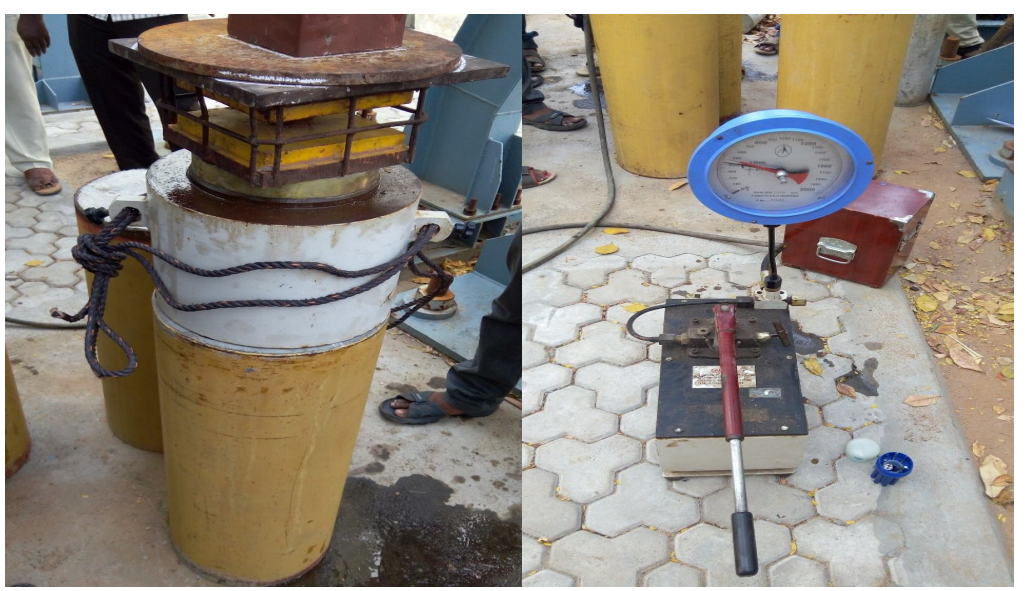

Fig 7: Application of loading from bottom with hydraulic jack

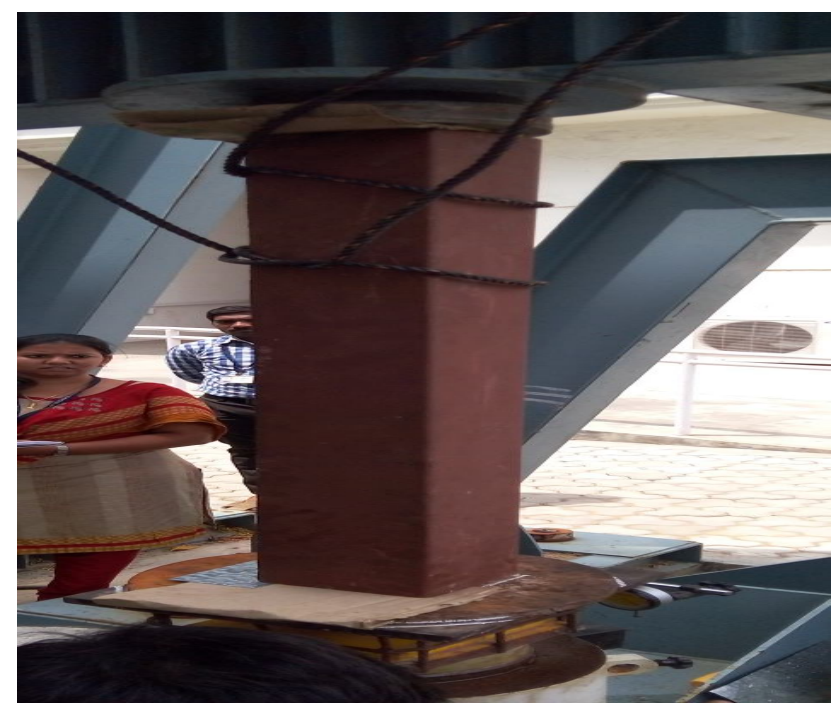

Fig10: Axial load testing of column

\section{FAILURE MODES OF COLUMN}

After the axial load testing of columns both the column undergoes local failure the failure modes of column are given below. The failure mode of column 1 without connectors is shown in Fig 10 and Fig 11. The simply supported conditions are used for testing of both the in filled composite column with and without connectors.

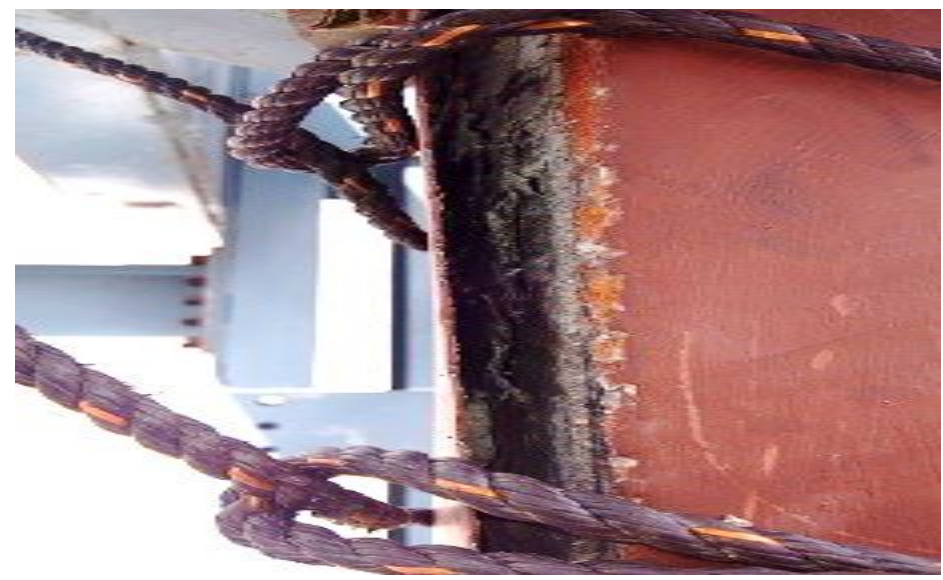

Fig 11. Local failure of column 1 without connectors 


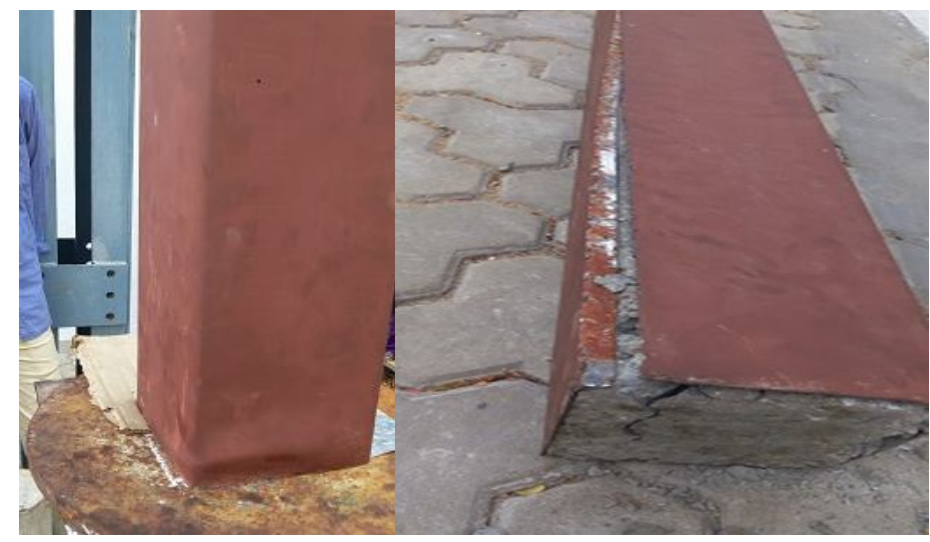

Fig 12: Local failure of column 1 without connectors

The column 2 with connectors on axial load testing undergoes same type of failure mode obtained in column 1 without connectors. The column undergoes local mode of failure. The modes of failures obtained in column 2 with connectors are shown below.

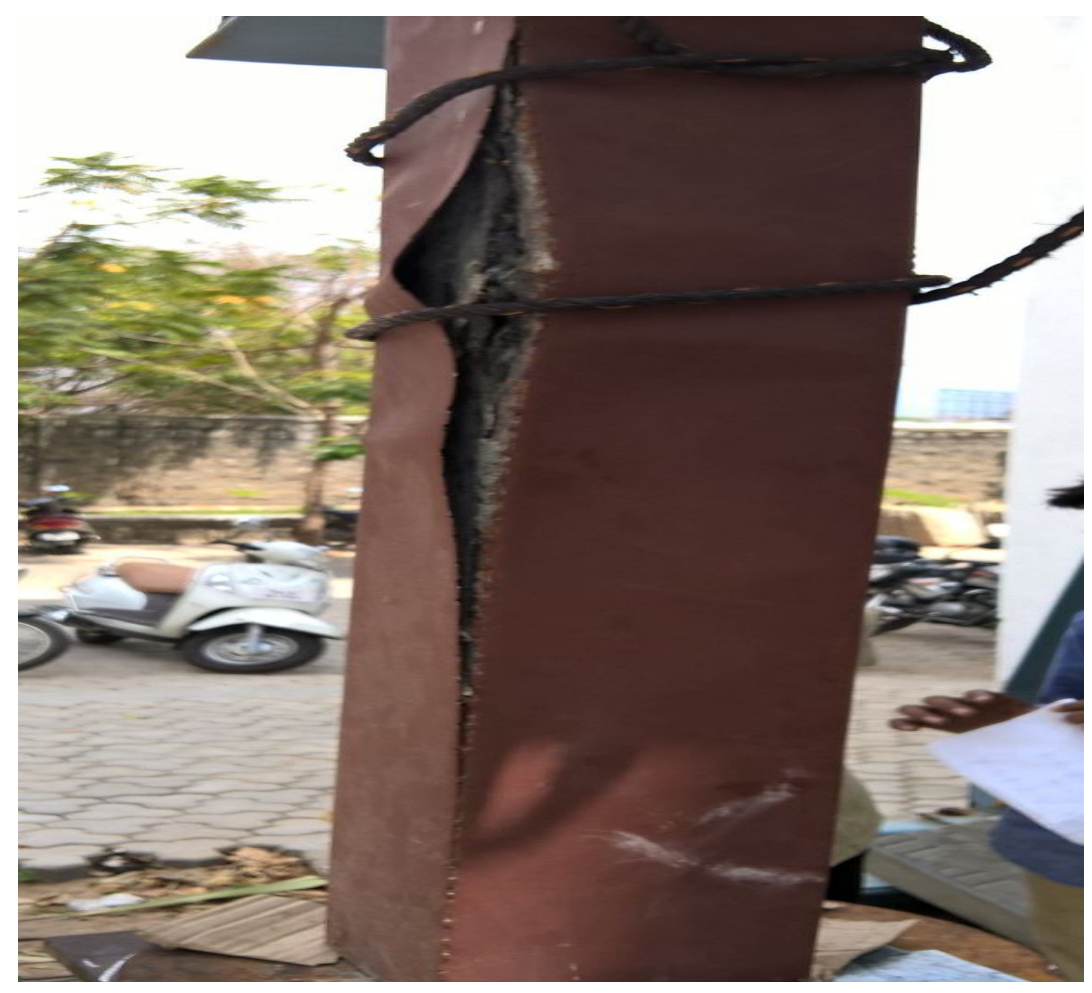

Fig 13. Local failure of column 2 with connectors 


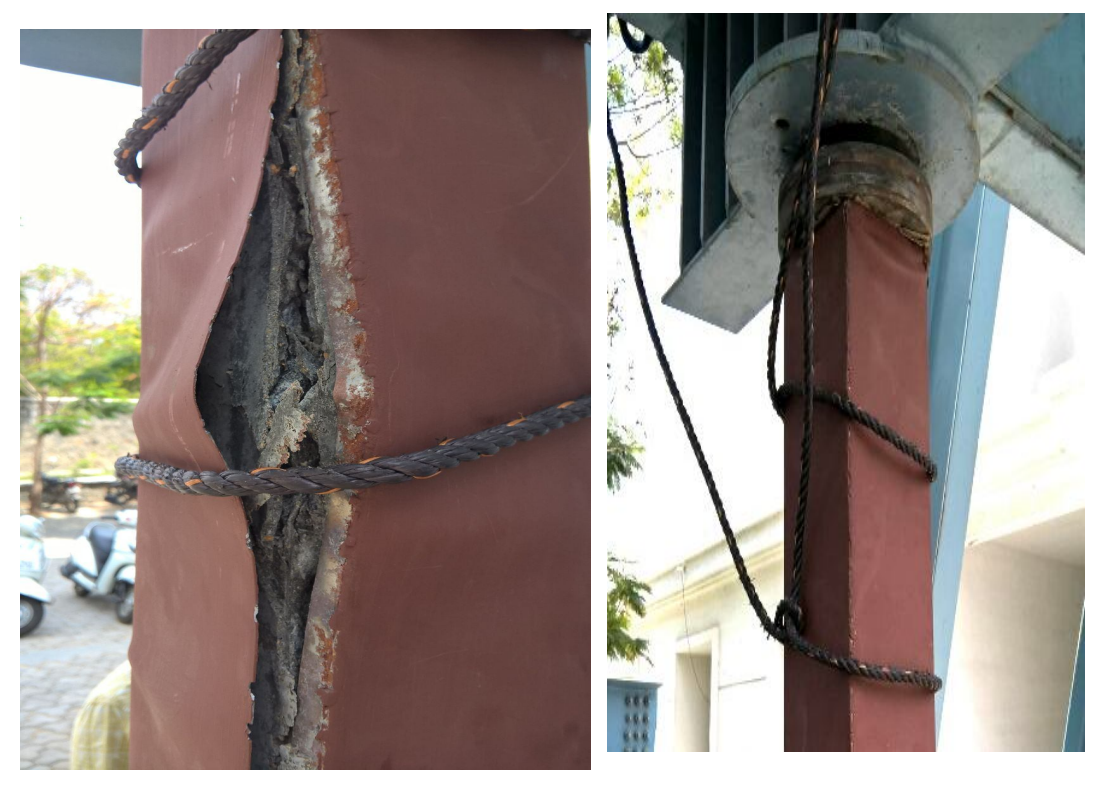

Fig 14. Local failure of column 2 with connectors

\section{RESULTS AND CONCLUSION}

The ultimate load obtained by experimental analysis of both the column with and without connectors from loading frame machine is given below.

1. Ultimate load of column 1 without connector- $480 \mathrm{kN}$

2. Ultimate load of column 2 with connector $-590 \mathrm{kN}$

3. Mode of Failure is local failure at the joints

4. Support conditions used simply supported condition.

\section{REFERENCES}

[1] Furlong RW. Strength of steel encased concrete beam-columns. Journal of the Structural Division, Proc. American Society of Civil Engineers 1967;93(ST5):115-30.

[2] Neogi PK, Sen HK, Chapman JC. Concrete-filled tubular steel columns under eccentric loading. The Structural Engineer 1969;47(5):187-95.

[3] Uy B, Patil SB. Concrete-filled high strength steel box columns for tall buildings: behaviour and design. The Structural Design of Tall Buildings 1996;5:75-93.

[4] Burr WH. Composite columns of concrete and steel. Proc. Institution of Civil Engineers 1912;188:114-26.

[5] Mirza SA, Skrabek BW. Reliability of short composite beam-column strength interaction. Journal of Structural Engineering, ASCE 1991;117(8):2320-39.

[6] Mirza SA, Skrabek BW. Statistical analysis of slender composite beam-column strength. Journal of Structural Engineering, ASCE 1992;118(5):1312-31.

[7] Hunaiti YM, Fattah BA. Design considerations of partially encased composite column. Proc. Institution of Civil Engineers, Structures \& Buildings 1994;106(Feb.):75-82.

[8] Ghosh RS. Strengthening of slender hollow steel columns by filling with concrete. Canadian Journalof Civil Engineering 1977;4(2):127-33.

[9] Prion HGL, Boehme J. Beam-column behaviour of steel tubes filled with high-strength concrete.

In: Fourth International Colloquium, SSRC, New York, 1989:439-49.

[10] Shakir-Khalil H, Zeghiche J. Experimental behaviour of concrete-filled rolled rectangular hollowsection columns. The Structural Engineer 1989;67(19):346-53.

[11] Shakir-Khalil H, Mouli M. Further tests on concrete-filled rectangular hollow section columns. The Structural Engineer 1990;68(20):405-13. 